\title{
CYTOTOXIC EFFECT OF AQUADEST, ETHANOLIC, AND CHLOROFORM EXTRACTS OF Spathoglottis plicata Blume ON BREAST CANCER CELLS LINE (T47D CELLS)
}

\author{
Mukhlish Jamal Musa Holle ${ }^{1,2, *)}$, Hestri Dyah Puspitasari ${ }^{1,2)}$, Andaru Satryo ${ }^{1,2)}$, Wahyu Dewi \\ Astuti Ningrum ${ }^{1,2)}$, Digdo Sudigyo ${ }^{1)}$, and Ardaning Nuriliani') \\ ${ }^{1}$ Faculty of Biology, Universitas Gadjah Mada, Jl. Teknika Selatan Sekip Utara Yogyakarta, 55281, Indonesia. \\ 2 Biology Orchid Study Club, Universitas Gadjah Mada, Jl. Teknika Selatan Sekip Utara Yogyakarta, 55281, \\ Indonesia. \\ *)Correspondence author: holle.mukhlish@gmail.com
}

\begin{abstract}
Breast cancer is one of cancer with high mortality. This cancer not only attacks women, but also men. Indonesia has many plants which potential as anticancer, such as orchids. Spathoglottis plicata is one of the orchid species that abundant in Indonesia and has a lot of antioxidant compounds which is guessed have anticancer properties. The objectives of this study were to study the cytotoxic activity and $\mathrm{IC}_{50}$ value of aquadest, ethanolic, and chloroform extracts of $S$. plicata's pseudobulbs, leaves, and whole plants on T47D cells (breast cancer cells line) as well as cytotoxic activity of the specific fraction of the most toxic crude extract. S. plicata used in this study was obtained from Bungarinte nursery. Extractions were done by maceration method using aquadest, ethanol, and chloroform as the solvent. Cytotoxic test on T47D cells were done by MTT assay. The cytotoxic data were analyzed using one-way ANOVA followed by Tukey's HSD test. The $I C_{50}$ of each extracts were calculate by probit analysis. The lowest $I C_{50}$ value among all extracts was fractionated and isolated by preparative TLC. The cytotoxic activity and $I_{50}$ of this fractions were analyzed. The results showed that only 2 from 9 crude extracts that able to calculate its $I_{50}$ because those two extracts have concentration dependent pattern of inhibition concentration. Chloroform extract have the lowest $I_{50}$ value $(369,837 \mu \mathrm{g} / \mathrm{mL})$. Then, this extract fractionated by eluen $\mathrm{n}$-hexane : ethyl acetate $4: 1$. Four fractions were collected. The lowest IC ${ }_{50}$ value is fraction IV $(144,41 \mu \mathrm{g} / \mathrm{mL})$. Based on the results it could be concluded that $S$. plicata leaves have moderate potency to develop as anticancet agents, especially on breast cancer.
\end{abstract}

Keywords: S. plicata, T47D cells, cytotoxic, MTT assay, preparative TLC.

\section{INTRODUCTION}

Breast cancer is one of cancer with high mortality. This cancer becomes the second killer cancer in the World and sixth in Indonesia (Histopaedianto et al., 2008). Late of diagnosis and treatment usually caused the death of sufferer. Breast cancer attacks both women and men. So far, the treatment to cure breast cancer is not completely safe and have side effects because this treatment not only attack cancer cells but also normal cells such as hair cells, bone marrow, and gastrointestinal cells (Rahmawati, 2009). It important to investigate new herbal medicine which potential as anticancer agents especially for breast cancer treatment.

Indonesia is a megabiodiversity country, especially for orchids biodiversity. Approximately, 5.000 of 25.000 orchid species in the world were found in Indonesia (Sandra, 2004). S. plicata have a high distribution and abundant enough in a lot of area in Indonesia (Sheehan, 1994). This orchid easy to cultivate and can grow in the many different habitat. So far, this orchid just utilized as ornamental plant.

ISSN 2413-0877 @ 2015 The Authors.

Published by KnowledgeE Publishing Services This is an open access article under the CC BY-NC-ND license (http://creativecommons.org/licenses/by-nc-nd/4.0)

Selection and Peer-review under responsibility of the 3rd ICBS-2013

Doi http://dx.doi.org/10.18502/kls.v2i1.118 
Previous study by Holle (2012), showed that S. plicata pseudobulbs and leaves have secondary metabolites such as alkaloid, flavonoid, and terpenoid. It has similar detected secondary metabolites with Dendrobium orchid which was already tested its anticancer potency through cytotoxic test on the HeLa cells (cervical cancer cell lines) (Nuriliani, 2013). Besides that, orchids are already used as medicine, such as diuretic, anti-rheumatic, antiinflammatory, anticarcinogenic, hypoglycemic activities, antimicrobial, anticonvulsive, relaxation, neuroprotective, and antivirus (Gutiérrez et al., 2010). The other orchid species such as Cephalanceropsis gracilis crude methanol extract of rhizomes showed significant cytotoxicity against human breast carcinoma (MCF-7), lung carcinoma ( $\mathrm{NCl}-\mathrm{H} 460$ ), and central nervous system carcinoma (SF-268) cell lines (Wu et al., 2006). Odontoglossum sp. was tested by MTT method and have potency to kill cancer cells (Masuda, 2011). Based on those researchs, it is guessed that $S$. plicata also have potency as anticancer agents. The objectives of this study were to investigate cytotoxic activity of $S$. plicata's pseudobulbs, leaves, and wholeplant extracts to the T47D cells, to analyze $I_{50}$ values of these extracts, and to determine cytotoxic activity of fraction of the most toxic extracts of $S$. plicata.

\section{MATERIALS AND METHODS \\ Plant Material and extraction}

S. plicata was collected from Bungarinte Nursery, Yogyakarta in mature conditions. S. plicata were divides on 3 samples, ie pseudobulbs, leaves, and wholeplants. The dried samples were grinded to the powder. Extractions were done by maseration method using ethanol $96 \%$, chloroform and aquadest independently.

\section{Cytotoxic Assay by MTT method (Ratnawati et al., 2008)}

Cytotoxic activity measured by MTT assay. T47D cell line is collected from Integrated Research and Testing Laboratory (LPPT) UGM. T47D cells cultured in complex medium (87,5\% RPMI+10\% FBS+0,5\% Fungizon+0,5\% Penstrep) inside Flask. After confluent, cells harvested and counted by haemocytometer. Each well on 96 platewell is filled by $2 \times 10^{4} \mathrm{cells} /$ $100 \mu \mathrm{L} /$ well on complete medium. 96 platewell incubated at $37^{\circ} \mathrm{C}, \mathrm{CO}_{2} 5 \%$ for 4 hours. Treatment is performed in triplicate. There were 4 variable that assessed, consist of cells control (T47D cells suspensionin complete medium), Solvent control (T47D cells suspension + complete medium + DMSO 0,125\%; 0,25\%; 0,5\%), Treatment group (Each extract by consentration 7,$815 ; 15,625 ; 31,25 ; 62,5 ; 125 ; 250 ; 500$ and $1.000 \mu \mathrm{g} / \mathrm{mL}$ on each $100 \mu \mathrm{L} /$ well) and positive control (Doxorubicin at consentration 3,906; 7,815; 15,625; and 31,25 $\mathrm{\mu g} /$ $\mathrm{mL}$ ). After treat the cells, 96 plate well incubated on $37^{\circ} \mathrm{C}, \mathrm{CO}_{2} 5 \%$ during 24 hours. In the end of incubation, every well added $10 \mu \mathrm{L} \mathrm{MTT}$ and incubated on $37^{\circ} \mathrm{C}, \mathrm{CO}_{2} 5 \%$ during 4 hours. Stopper reagent, SDS $10 \%$ in $\mathrm{HCl} 0,1 \mathrm{~N}$ as much as $100 \mu \mathrm{L} /$ well, stop MTT reaction. Then, Platewell assessed by ELISA reader $(550 \mathrm{~nm})$. Inhibition percentage calculated by below formula:

$$
\% \text { Inhibition }=\frac{(\text { Cells control abs. }- \text { treatment abs. })}{\text { Cells control abs. }} \times 100 \% \quad \text { (Ratnawati, 2008) }
$$




\section{Fractionation by Preparative Thin Layer Chromatography (PTLC)}

The extract which have the lowest IC50 value was fractionated and scraped out by preparative TLC method using eluen n-hexane:ethyl acetate 4:1. Obtained fractions from TLCP were tested for cytotoxic activity by MTT assay.

\section{Data analysis}

The different among treatments were analyzed by ANOVA followed by Tukey HSD test. $I C_{50}$ (Inhibition Concentration 50) was calculated using probit analysis. The higher activity of extracts was determined by their lower $\mathrm{IC}_{50}$ value.

\section{RESULTS AND DISCUSSION}

\section{Cytotoxic activity of S. plicata crude extracts}

T47D cells are typically breast cancer cells which get missense mutation on 194 residue on p53 gene and caused this gene dysfunction. This gene dysfunction makes cell regulation fail (Da'i et al., 2007). Cytotoxic activity was able measured on the dependent concentration pattern of inhibition percentage. Two of nine crude extracts able to measure this cytotoxic activity, ie chloroform leaves extract and chloroform wholeplants extract. Cell growth inhibition treatment groups of $S$. plicata extracts, solvent control (DMSO and tween), and positive control (Doxorubicin) were showed in Figure 1. Solvent controls used to make sure that the DMSO and tween have no killing effects to the cells. Inhibition percentage of solvent controls almost zero so it does not affect T47D cells viability.

$\mathrm{IC}_{50}$ (Inhibition Concentration 50) is a concentration that can kill $50 \%$ of cells in cell populations. The lower $I_{50}$ value, the higher potency of extract to inhibit cell growth. $I C_{50}$ values of chloroform leaves extract was $(369,837 \mu \mathrm{g} / \mathrm{mL})$ and chloroform wholeplants extract $(1312.767$ $\mu \mathrm{g} / \mathrm{mL}$ ). Based on like-dissolve-like principle, chemical that potential as anticancer compounds in both of these extracts have non-polar properties. Leaves extract have higher cytotoxic activity than wholeplants because leaves are specified organ that synthesized chemical compound such as secondary metabolite.

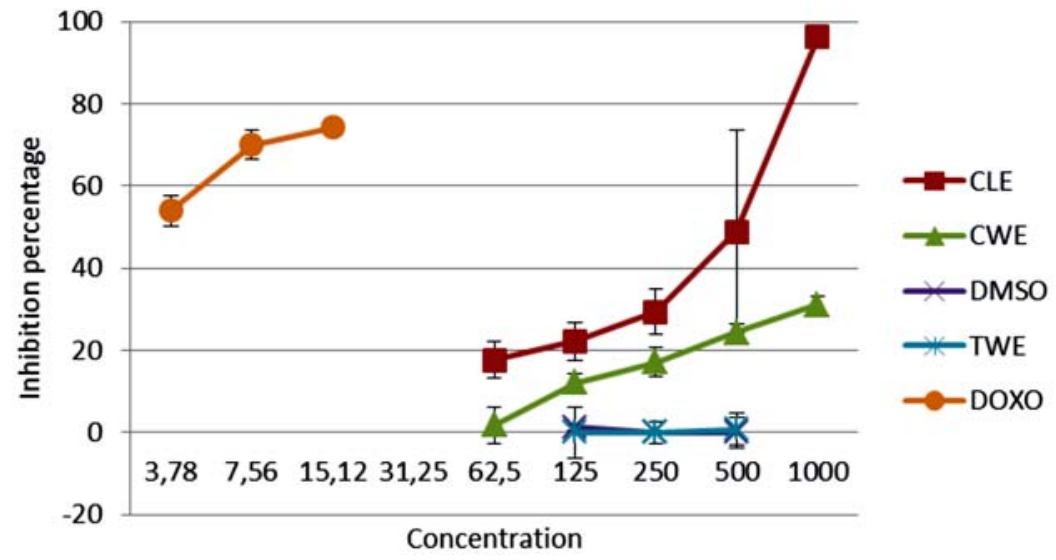

Figure 1. Inhibition percentage of $S$. Plicata's extracts on the T47D cells. Abbreviation: CLE:Chloroform leaves extracts; CWE : Chloroform wholeplants extracts; DMSO: Dimethyl sulfoxide; TWE : Tween 20; and DOXO: Doxorubicin. 
S. plicata's leaves were contained secondary metabolites, ie alkaloid flavonoid and terpenoid (Holle et al, 2013). Alkaloid compounds on Acronychia baueriSchott, Camptotheca acuminata, Catharanthus roseus, Uncaria tomentosa, and Viscum album were reported have antitumor activity (Agarwal et al., 2012). Total alkaloid of Tabebuia rosea extract have antiproliferative potency on MOLT-4 cells (Sathiya \& Muthuchelian, 2010). Flavonoid on Glycyrrhiza inflata have potency to develop as chemotherapy agents on cervix cancer treatment because it can inhibit cancer cells growth and apoptosis induction by isoliquiritigenin and chalcone A (Xia et al., 2013). Flavonoid also have potency on inhibition of carcinogen metabolic inhibition, antiproliferation, apoptosis induction, antioxidants activity, and angiogenesis inhibition (Ren et al., 2003; Kanadaswami et al., 2005). Terpenoid, such as monoterpene, diterpene, triterpene, tetraterpene, and sesquiterpene, have potency as chemotherapeutic and therapeutic agents to the liver cancer (Thoppil \& Bishayee, 2011).

Cytotoxic activity potency were divided to 3 groups, ie weak ( $\left(\mathrm{IC}_{50} \mathrm{e}=50 \mu \mathrm{g} / \mathrm{mL}\right.$ ), moderate $\left(10 \mu \mathrm{g} / \mathrm{mL}<\mathrm{IC}_{50}<50 \mu \mathrm{g} / \mathrm{mL}\right)$, and active $\left(\mathrm{IC}_{50} \mathrm{~d}\right.$ ' $\left.10 \mu \mathrm{g} / \mathrm{mL}\right)$. It possible that S. plicata's leaves extract has better cell growth inhibition on different kind of cells cultures (Syarifah et al., 2011).

\section{Cytotoxic activity of chloroform leaves extract fraction}

On TLCP using eluen n-hexane:ethyl acetate $4: 1$ was produce 4 fraction with Rf value 97,$14 ; 41,90 ; 20,95$; and 10,47 respectively (Table 1 ). It show that this fraction is the source of toxicity of $S$. plicata chloroform leaves extract.

Table 1. Rf values and $I C_{50}$ of chloroform leaves extract fraction on the T47D.

\begin{tabular}{ccc}
\hline Fraction & $\mathrm{Rf}(-)$ & $\mathrm{IC}_{50}(\mu \mathrm{g} / \mathrm{mL})$ \\
\hline I & 97,14 & 1169,37 \\
II & 41,90 & 305,64 \\
III & 20,95 & 182,02 \\
IV & 10,47 & 144,41 \\
\hline
\end{tabular}

The inhibition percentage (\%) of treatment groups fraction of S. plicata chloroform leaves extract, solvent control (tween), and positive control (Doxorubicin) showed in Figure 1. Solvent controls used to check the effect of solvent and the results were compared with the cytotoxicity of treatments. The results indicated that solvent control (tween) did not show any significant effect on human cancer cell lines. Inhibition percentage of solvent controls almost zero so it does not affect T47D cells viability.

The results (Figure 2.) showed that fraction IV have higher cytoxic than all fractions. $I C_{50}$ values of fraction IV is $144,41 \mu \mathrm{g} / \mathrm{mL}$. Fraction IV of chloroform leaves extract have higher cytotoxic activity than crude extract of chloroform leaves extract. Purified fraction using PTLC were reported have more effective and higher cytotoxic activity to the cancer cells than crude extract (Sampath \& Vasanthi, 2013; Shriram et al., 2010). 


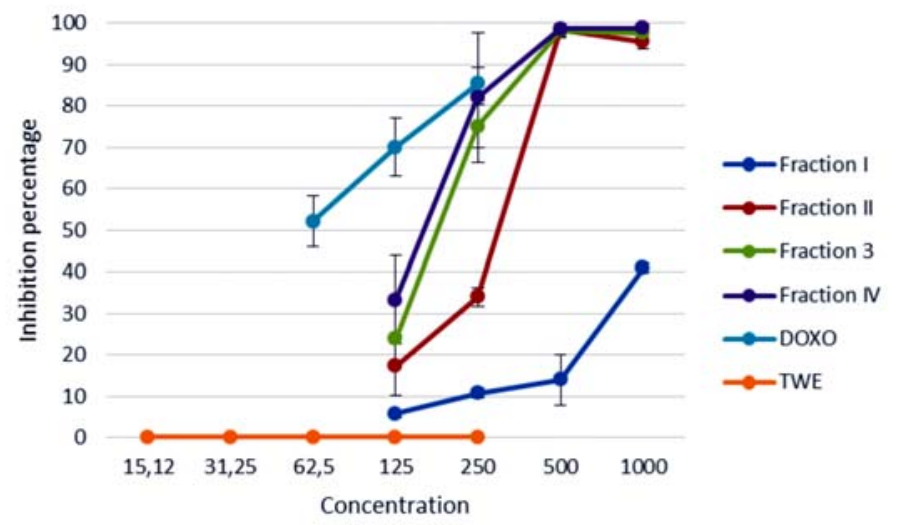

Figure 2. Inhibition percentage of chloroform leaves extract fractions of S. plicata on the T47D cells. Abbreviation: DOXO: Doxorubicin and TWE : Tween 20.

\section{CONCLUSION}

S. plicata extracts have a cytotoxic activity to T47D cell, especially on chloroform leaves extract and chloroform wholeplants extract. $\mathrm{IC}_{50}$ value of chloroform leaves extract more potential as anticancer agents. Fractions of chloroform leaves extract also have higher cytotoxic activity than crude extract with the moderate anticancer activity on breast cancer and need to be investigated further.

\section{ACKNOWLEDGMENT}

We acknowledge to Directorate of Higher Education Ministry of Education through Student Creativity Program as financial funding.

\section{REFERENCES}

Agarwal, N., C. Majee, and G.S. Chakraborthy. 2012. Natural herbs as anticancer drugs. International Journal of Pharm Tech Research, Vol. 4(3): 1142-1153.

Da'i, M., U.A. Jeniel, A.M. Supardjan, M. Kawaichi, and E. Meiyanto. 2007. T47D cells arrested at G2M and hyperploidy formation induced by a curcumin's analogue PGV-1. Indonesian Journal of Biotechnology, Vol 12(2) : 1007.

Gutiérrez, R.M.P. 2010. Orchids: A review of uses in traditional medicine, its phytochemistry and pharmacology. Journal of Medicinal Plants Research, Vol. 4(8): 592-638

Histopaedianto, I., L. Choridah, and T. Aryandono. 2008. Validity of BI-RADS System Mammography to detect breast cancer at Dr. Sardjito Hospital Yogyakarta. Berkala IImu Kedokteran, Vol. 40 (1) 20-25.

Holle, M. J. M., F. R. Arfriana, and W.A.S. Tunjung. 2013. Detection of alkaloid, flavonoid, and terpenoid compounds of ethanolic and chloroform of pseudobulbs and leaves extracts on Dendrobium mutabile (Blume) Lindl. and Spathoglottis plicata Blume, Proceeding of The $10^{\text {th }}$ Hokkaido Indonesian Student Association Scientific Meeting : 1-5

Kanadaswami, C., L. Lee, P.H. Lee, J. Hwang, F. Ke, Y. Huang, and M. Lee. 2005. The antitumor activities of flavonoids. in vivo, Vol. 19: 895-910

Ren, W., Z. Qiao, H. Wang, L. Zhu, and L. Zhang. 2003. Flavonoids: promising anticancer agents. Medicinal Research Reviews, Vol. 23 (4): 521-528 
Masuda, Y., J. Ueda, M. Tamura, H. Sakagami, M. Tomomura. A. Tomomura and Y. Shirataki. 2011. Diverse biological activity on Odontoglossum Harvengtense 'Tutu' bulb extracts. In Vivo, Vol. 25: 381-386

Nuriliani, A., N. Wijayanti, A. Kusmiyati, Y. A. Purwestri, and R. Topriyani. 2013. Growth inhibition, apoptosis induction, and antiangiogenesis activity of ethanolic extract of Dendrobium crumentum Swartz. Proceeding of The First Annual International Scholar Conference in Taiwan, ISSN:2337-442X : 587-595.

Rahmawati, Z.N, 2009. Evaluasi penggunaan antiemetic dalam penatalaksanaan mual muntah karena kemoterapi pada pasien kanker payudara di RSUD Dr Moewardi Surakarta tahun 2008. Skripsi. Universitas Negeri Sebelas Maret Surakarta.

Ratnawati, H., W. Widowati, D.K. Jasaputra, and S. Soeng, 2008. Cytotoxic activity of buah merah fractions (Pandanus conoideus Lam.) towards cervical cancer cell in HeLa cells culture. Proceeding ot The International Seminar on Chemistry, P:317-320.

Sampath, M., and Vasanthi M. 2013. Isolation, structural elucidation of flavonoids from Polyathia longifolia (Sonn.) thawaites and evaluation of antibacterial, antioxidants, and anticancer potential. International Journal of Pharmacy and Pharmaceutical Sciences, Vol. 5: 336-341.

Sandra, E. 2004. Kultur Jaringan Anggrek Skala Rumah Tangga. AgroMedia Pustaka., Jakarta. $P: 1$

Sathiya, M., and K. Muthuchelian. 2010. Antitumor potential of total alkaloid extract from Tabebuia rosea (Bertol.) DC. leaves on MOLT-4 cells in vitro. Nature and Science, Vol. 8(9): 7

Sheehan, T., and M. Sheehan. 1994. An illustrated survey of orchid. Cambridge University Press. Cambridge.

Shriram, V., V. Kumar, P.B.K. Kishor, S.B. Suryawanshi, A.K. Upadhyay, and M.K. Bhat. 2010. Cytotoxic activity of 9,10-dihydro-2,5-dimethoxyphenanthrene-1,7-diol from Eulophia nuda against human cancer cells. Journal of Ethnopharmacology, Vol. 128 : 251-253

Thoppil, R.J., and A. Bishayee. 2011. Terpenoids as potential chemopreventive and therapeutic agents in liver cancer. World J Hepatol, Vol. 3(9) : 228-232.

Wu, P., Y. Hsu, and C. Jao. 2006. Indole alkaloids from Cehpalanceropsis gracilis. American Chemical Society and American Society of Pharmacognosy.

Xia, G., R. Matsidik, M. Ablise, S. Lei, and A. Abudula. 2013. Anti-cancer activity of flavonoids from Xinjiang Glycyrrhiza inflata Licorice on proliferation, cytotoxicity and apoptosis in cervical carcinoma cells. Journal of Medicinal Plants Research, Vol. 7(5): 173-178. 